\title{
The Role of Macroeconomic Variables on Stock Market Index in China and India
}

\author{
Seyed Mehdi Hosseini \\ School of Management, University Sains Malaysia \\ Tel.: 60-17-450-7989 E-mail: seyed_mehdi_hosseini80@yahoo.com \\ Zamri Ahmad \\ School of Management, University Sains Malaysia \\ E-mail: zahmad@usm.my \\ Yew Wah Lai \\ Graduate School of Business, University Sains Malaysia \\ E-mail: ywlai@usm.my
}

Received: May 7, 2011

Accepted: May 30, 2011

Published: November 1, 2011

doi:10.5539/ijef.v3n6p233

URL: http://dx.doi.org/10.5539/ ijef.v3n6p233

\begin{abstract}
This paper investigates the relationships between stock market indices and four macroeconomics variables, namely crude oil price (COP), money supply (M2), industrial production (IP) and inflation rate (IR) in China and India. The period covers in this study is between January 1999 to January 2009. Using the Augmented Dickey-Fuller unit root test, the underlying series are tested as non-stationary at the level but stationary in first difference. The use of Johansen-Juselius (1990) Multivariate Cointegration and Vector Error Correction Model technique, indicate that there are both long and short run linkages between macroeconomic variable and stock market index in each of these two countries.
\end{abstract}

Keywords: Crude oil price, money supply, Industrial production, Inflation rate, Stock market index

\section{Introduction}

Although there are a number of empirical studies on the effect of macroeconomic variables on stock market indices, most of these studies typically focused on developed economies and the effects of these macroeconomic factors on the stock market indices in less developed Asian countries (e.g. Iran, Indonesia, Singapore, Thailand, Malaysia, China, India etc.) is less obvious. Specifically, how do these less-developed markets react to changes in its fundamental macroeconomic variables such as crude oil price, money supply, industrial production and inflation rate?

Moreover, the literature rarely has studied the potential impact that macroeconomic variables may have on developing stock market index and how understanding of this relationship can help investors to diversify their portfolio and choose a country for investment to increase their return by using the same risk that they previously had. It means international diversification can reduce risk. In addition there is a gap in literature when we want to compare two economies for choosing a country to put in portfolio. In addition, there are fewer studies which look at the potential benefits of knowing this relationship especially in making a portfolio when we have crisis in oil, credit and inflation. This is due to the fact that the literature on multifactor models in developing markets has focused primarily on either microeconomic effects such as dividend yields and price-to-earnings ratios or the effect of world impacts such as the world equity portfolio. It is obvious that any major movement in oil prices leads to uncertainties in the stock market. These uncertainties could influence investors to suspend or delay their investments. In addition, increases in oil prices result in higher transportation, production and heating costs, which have negative effect on corporate earnings. Rising fuel prices also raise concerns about inflation and diminish consumers' discretionary spending. Therefore, the financial risk of investments increases when there is wide fluctuation in oil prices. An increase in money supply results in increased liquidity available for buying securities, resulting in higher security prices. On the other hand, an increase in money supply could also result in increased inflation, which in turn may 
trigger an increase in interest rate and dampen stock prices. Industrial production, which reflects real economic activity, affects the stock market index positively. As industrial production increases, sales and earnings of firms rise, which leads to increases in stock prices as investors feel confident of investments in the stock market. When inflation rises it is likely to lead to tight monetary policies, which result in increase in the discount rate. It means the cost of borrowing increases, which in turn leads to investment reduction in the stock market. By looking at effect of major macroeconomic variables on stock market index in China and India, we are going to consider and compare economic environment in these two countries for investment purposes.

The rate at which China and India have been developing since the early 1990's has been one of the main issues of interest around the world. Both countries have more than a billion people and they experience impressive GDP growth rate each year. Some of key indicators of these two countries have shown in Table 1.

A major reason that makes India and China an interesting comparison is that, these two countries have different economic environment. As a result it is necessary for an investor to have a good knowledge of the unique features of the two economies before making a rational decision on where to place his investment. It is vital to understand both the differences and the opportunities available in the two economies.

\section{Insert Table 1 here}

The monthly data used in this paper cover the period January 1999 to January 2009. This paper aims to enhance the investor understanding and evaluation in terms of sensitivity of the respective stock market index to the systematic impact of macroeconomic factors of crude oil price, inflation rate, money supply growth rate, and industrial production growth rate.

In this paper, we will draw upon theory and existing empirical studies to choose a number of macroeconomic variables that are expected to be strongly related to the stock market index. We employ these variables, in a cointegration model, to compare and contrast the performance of the stock market index in the China and India. The knowledge on the relationship between the macroeconomic variables and stock market performance would enhance the ability of investors to make optimal decision in their business investments globally.

\section{Literature review}

They are many empirical studies that tried to find how oil price affect stock market index and in which sector, it has more effect. For example, Sadorsky (2001) found a rise in oil price increases the return to Canadian oil and gas stock sector prices and Park and Ratti (2008) also showed that shocks in oil price have a significant effect on stock returns in the same month or within one month. But Cong, Wei, Jiao, \& Fan (2008) showed that oil price shocks or volatility has no statistically significant effect on the real stock returns of most Chinese stock market indices, except on some manufacturing indices and indices of some oil companies. Another study by Nandha and Faff (2008) also indicated that increase in oil price has a negative effect on stock returns for most sectors except mining and some related industries such as oil and gas industries. In addition, Sadorsky (2008) showed that increases in firm size or oil prices reduce stock market price returns, and increases in oil prices have more impact on stock market returns than decreases in oil prices do. Our prior expectation in this study is that the effect of increase in crude oil price on stock market index in China and India is negative.

On the other hand, According to the monetary portfolio theory, the volatility in money supply alters the equilibrium position of money, hence altering the composition and assets price in an investor's portfolio (Rozeff, 1974). Moreover, innovations in money supply may affect real economic variables which may lead to a lagged positive impact on stock returns (Rogalski and Vinso, 1977).

Money supply is likely to affect stock market index through at least three ways: first, innovations in the money supply may be correlated to unexpected increases in inflation and future inflation uncertainty and thus, negatively correlated to the stock market index. Second, innovations in the money supply may positively affect the stock market index through its effect on economic activity and finally, portfolio theory says a positive relationship exists, since it relates a rise in the money supply to a portfolio change from noninterest bearing money to financial assets including equities.

In this regards Lastrapes and Selgin (1995) find that money supply has a dynamic effect on price of real equity and Pebbles and Wilson (1996) indicated that when an appreciating currency happens, it is generally accompanied by increases in reserves, money supply and decreases in interest rates. As a result, the cost of capital and imported inputs decrease, leading to an increase in local equity returns. Moreover, Mookerjee and Yu (1997) find that money supply and foreign exchange reserves have a long run relationship with stock prices in Singapore. In another study Maysami and Koh (2000) showed a positive relation between money supply innovation and stock market returns in Singapore. Then study by Wongbangpo and Sharma (2002) showed that in the ASEAN-5 countries, high inflation in 
Indonesia and Philippine leads to a long run negative relationship between stock prices and the money supply, while the money growth in Malaysia, Singapore and Thailand causes a positive effect on their stock market indices. Our prior expectation is that the effect of increase in money supply on stock market index in China and India is positive.

In the case of the impact of industrial production, theory states that corporate cash flows are correlated to a dimension of aggregate output such as Gross Domestic Product (GDP) or industrial production and many. Moreover, Fama (1981) suggests that measures of economic activity such as industrial production and inflation have important roles in the analysis of stock market activity. Geske and Roll (1983) suggested a positive linkage between industrial production and stock market prices. Then Asprem (1989) also found that real economic activity such as industrial production, exports, and money are positively correlated to stock prices. In another study Nasseh and Strauss (2000) found the existence of a strong, long-run relationship between stock prices and domestic and international economic activity in six European economies. Moreover, Campbell, Lettau, Malkiel, and Xu (2001) in their study on the macroeconomic determinants of stock market changes have concentrated on the industrial production growth rate as a measure of business-cycle fluctuations. Kim (2003) in his study found that the S\&P 500 stock price has a positive correlation with industrial production but negative relationship with the real exchange rate, interest rate, and inflation. In another empirical research Ewing and Thompson (2007) also explored the cyclical correlation between industrial production, consumer prices, unemployment, and stock prices using time series filtering methods. All these studies are showing the importance of this variable to take into consideration. As a result our prior expectation is that the effect of increase in industrial production on stock market index in China and India is positive.

On the other hand, unexpected inflation may also directly affect the stock market index negatively through unexpected innovations in the price level. Inflation uncertainty may also influence the discount rate, thus decreasing the present value of future corporate cash flows. The study by Malkiel (1982) showed a negative relationship between inflation rate and stock market prices. This is due to two reasons. First, a rise in the rate of inflation tends to increase interest rate, which may then lead to the lower prices of equities. Second, an increase in inflation rate may squeeze profit margins for special groups of companies such as public utilities, leading to a decrease in their stock prices. Omran and Pointon (2001) indicated that there is a negative correlation between inflation and market activity and liquidity, and also between inflation rate and both stock market return and prices. The same result has found by Boyd, Levine, \& Smith (2001) who indicated that there is a significant, negative correlation between inflation rate and growth in the banking sector and equity market activities. Moreover, Apergis and Eleftheriou (2002) study showed that inflation influences stock prices negatively in an economy with high inflationary pressures, such as Greece. Their findings showed that in Greece, if inflation decreases, the stock prices goes up. In another study Du (2006) showed that the positive correlation between returns in stock market and inflation in the 1930s is mainly due to strongly pro-cyclical monetary policy. However, the strong negative relationship of stock returns and inflation over the period 1952-1974 is because of supply shocks during this period. Our prior expectation is that the effect of increase in inflation on stock market index in China and India is negative.

Insert Table 2 here

\section{Methodology}

\subsection{Model specification and Data}

To analyze the short run and long run relationships between the macroeconomic variables and the stock market indices in the two countries the following modelsgiven in Equations (1) and (2) are used.

$$
\begin{aligned}
\mathrm{BSE}_{\mathrm{t}} & =\mathrm{f}\left(\mathrm{M} 2_{\mathrm{t}}, \mathrm{IP}_{\mathrm{t}}, \mathrm{IR}_{\mathrm{t}} \text {, and } \mathrm{COP}_{\mathrm{t}}\right) \\
\mathrm{SSE}_{\mathrm{t}} & =\mathrm{f}\left(\mathrm{M} 2_{\mathrm{t}}, \mathrm{IP}_{\mathrm{t}}, \mathrm{IR}_{\mathrm{t}} \text {, and } \mathrm{COP}_{\mathrm{t}}\right)
\end{aligned}
$$

The indices used are Bombay Stock Exchange (BSE) and Shanghai Stock Exchange index (SSE). The macroeconomic variables are crude oil price (COP) and money supply (M2), industrial production (IP) and inflation rate (IR), all in logarithm except for inflation rate. Monthly data are obtained from Datastream and the period covered is from January 1999 to January 2009.

\subsection{Unit Root Test}

Testing for non stationary time-series data has been one of the main developments in econometrics over the past quarter-century or so. In time series studies, when a simple linear regression model is used to analyze the relationship among non-stationary variables, it is possible that the resulting estimated equation is a spurious one. It means the "levels" of many economic time-series are integrated or nearly so, and that if such data are used in a regression model has a very high $\mathrm{R}^{2}$ even though these variables are independent of each other. According to Stock and Watson (1989), when a model consists of non-stationary variables, the usual test statistic ( $t$ test and $F$ test) would not have the standard distribution. Thus, it is imperative that non-stationary tests on variables should be 
carried out before proceeding to estimating the model. A non-stationary time series can be converted to a stationary series if differenced appropriately. A time series, is said to be integrated of order $\mathrm{d}$ (has $\mathrm{d}$ unit roots) if it becomes stationary after being differenced $d$ times. One of the common methods to find the order of integration of variables is the unit root test. There are numerous unit root tests. One of the most popular among them is the Augmented Dickey-Fuller (ADF) test. Augmented Dickey -Fuller (ADF) is an extension of Dickey -Fuller test. The ADF $(1979,1981)$ Test entails regressing the first difference of a variable y on its lagged level, exogenous variable(s) and $\mathrm{k}$ lagged first differences:

$$
\Delta Y_{t}=\alpha+\beta T+\rho Y_{t-1}+\sum_{i=1}^{k} \gamma_{i} \Delta Y_{t-i}+e_{t}
$$

where $Y_{t}$ is the variable in period $\mathrm{t}, \mathrm{T}$ denotes a time trend, $\Delta$ is the difference operator, $e_{t}$ is an error term disturbance with mean zero and variance $\sigma^{2}$, and $\mathrm{k}$ represents the number of lags of the differences in the ADF equation. The ADF is restricted by its number of lags. It decreases the power of the test to reject the null of a unit root, because the increased number of lags necessitates the estimation of additional parameters and a loss of degree of freedom. The number of lags is being determined by minimum number of residuals free from auto correlation. This could be examined for the standard approach such as Akaike's Information Criterion (AIC) and Schwartz Criterion (SC). The augmented specification is then used to test: $\mathrm{H} 0: \rho=0$ against $\mathrm{H} 1: \rho<0$

The null hypothesis of unit root is rejected against the one-sided alternative if t-statistic of $\rho$ is less than the MacKinnon critical values. This means that the variable is stationary.

\subsection{Multivariate Cointegration Test}

Most macroeconomic variables are non-stationary time series, with time-dependent means and variances. However, a linear combination of non-stationary variables may be stationary. In general, a set of variables are cointegrated if a linear combination of the integrated series is stationary. This linear combination is called the cointegrating equation and reflects a long-run equilibrium relationship among the variables. Various approaches have been employed to examine for cointegration in multivariate models, for instance, Engle-Granger procedure (Engle and Granger, 1987), dynamic ordinary least squares (Stock and Watson, 1993), Johansen-Juselius procedure (Johansen and Juselius, 1990) and Bounds Test (Pesaran et al 2001). This paper employs the Johansen-Juselius procedure to examine for cointegration. In essence, the approach is a multivariate generalization of the Augmented-Dickey-Fuller test (ADF). Consider a reduced form VAR of order $\mathrm{p}$ :

$$
y_{t}=A_{1} y_{t-1}+\ldots+A_{p} y_{t-p}+B x_{t}+u_{t}
$$

where $y_{t}$ is a $k$-vector of $\mathrm{I}(1)$ variables, $x_{t}$ is a n-vector of deterministic trends, and $u_{t}$ is a vector of innovations. We can rewrite this VAR as:

$$
\Delta y_{t}=\Pi y_{t-1}+\sum_{i=1}^{p-1} \Gamma_{i} \Delta y_{t-i}+B x_{t}+u_{t}
$$

Where $\Pi=\sum_{i=1}^{p} A_{i}-I, \Gamma_{i}=-\sum_{j=t+1}^{p} A_{j}$

The $\Pi$ matrix reveals the adjustment to disequilibrium following an exogenous shock. If $\Pi$ has reduced $\operatorname{rank} \mathrm{r}<\mathrm{k}$ where $\mathrm{r}$ and $\mathrm{k}$ indicate the rank of $\Pi$ and the number of variables respectively, then there exists two $\mathrm{k} \times \mathrm{r}$ matrices $\alpha$ and $\beta$, each with rank $\mathrm{r}$, such that $\Pi=\alpha \beta^{\prime}$ and $\beta^{\prime} y_{t}$ is stationary. The cointegration rank is given by $\mathrm{r}$ and each column of $\beta$ is a cointegrating vector (showing a long-run relationship). The elements of the $\alpha$ matrix represent the adjustment or loading coefficients, and give the speed of adjustment of the endogenous variables in response to disequilibrating shocks, while the elements of the $\Gamma$ matrices capture the short-run dynamic adjustments. The test procedure relies on relationships between the rank of a matrix and its characteristic roots (or eigenvalues). The rank of $\Pi$ equals the number of its characteristic roots that differ from zero, which in turn corresponds to the number of cointegrating vectors. The model uses the trace test statistics and the maximum eigenvalue test statistics to determine the number of cointegrating vectors.

\subsection{Vector Error Correction Model (VECM)}

The principle behind this model is that there often exists a long-run equilibrium correlation between two or more variables. In the short run, nevertheless, there may be disequilibrium. With the error correction mechanism, a proportion of the disequilibrium in one period is corrected in the next period. The error correction procedure is hence a way to reconcile short-run and long-run behavior. It relates the shift in $\mathrm{y}$ to the shift in $\mathrm{x}$ and the past period's disequilibria. 
A vector error correction (VEC) model is a restricted VAR that has cointegration restrictions built into the specification, so that it is designed for use with nonstationary series that are known to be cointegrated. The VEC specification restricts the long-run behavior of the endogenous variables to converge to their cointegrating relationships while allowing a wide range of short-run dynamics. The error correction model is based on the following equation:

$$
\Delta \mathrm{Y}_{t}=\beta_{0}+\beta_{1} e_{t-1}+\sum_{i=1}^{m} \beta_{i} \Delta \mathrm{Y}_{t-i}+\sum_{j=1}^{n} \beta_{j} \Delta X_{t-j}+\varepsilon_{t}
$$

where $e_{t-1}$ means the error-correction term lagged one period achieved from the cointegration equation. The error correction terms $\left(e_{t-1}\right)$ will capture the speed of the short run adjustments towards the long run equilibrium.

\section{Results}

\subsection{Unit Root Test}

To see the order of integration of the variables in our data set, we employ the standard ADF unit root test. Table 3 reveals that at the level, all the five variables are non-stationary since the unit root tests are not rejected, except for money supply in China and industrial production and inflation in India.

The variables used in this study are log of crude oil price (COP), log of money supply (M2), log of industrial production (IP), inflation rate (IR), log of Shanghai Stock Exchange (SSE) and log of Bombay Stock Exchange (BSE). The results indicate that at the first difference, all five series in the two countries are stationary.

Insert Table 3 here

\subsection{Multivariate Cointegration Test}

There are various approaches to test for cointegration in multivariate models. The Engle and Granger (1987) and the Johansen-Juselius method (Johansen, 1988; Johansen-Juselius, 1990) are two common approaches used to estimate cointegration equations. This study is based on the full information Johansen Maximum Likelihood (JML) procedure.

Tables 4 shows the Johansen-Juselius cointegration test findings based on the trace statistics ( $\lambda$ trace) and maximum eigenvalues $(\lambda \max )$ in each of these two countries. In both countries both the maximum eigenvalue test and trace test indicate that stock exchange index and its determinants have long-run relationship and are moving together in the long-run (equation 7 and 8).

Insert table 4 here

The results in each of these two countries suggest two cointegrating vectors. The existence of multiple cointegrating vectors is regarded as an identification problem. This may be solved by choosing the particular cointegrating vector where the long-run estimates correspond closely to those predicted by economic theory.

\subsection{Vector Error Correction Models (VECM)}

To find the short run correlation between macroeconomic variables and stock market indices in these two countries, this paper employs the VECM test. The VECM results are shown in table 5 for China and Table 6 for India.

\subsection{Cointegraion and VECM results-case of China}

$\mathrm{SSE}=84.45+0.028 \mathrm{COP}+0.701 \mathrm{M} 2-17.74 \mathrm{IP}+0.139 \mathrm{IR}$

Based on the cointegration results in the above equation, the long-term impacts of crude oil price, money supply and inflation rate on Chinese stock index are positive. However, the effect of increases in industrial production on China is negative.

\section{Insert Table 5 here}

In the short run, contemporaneous impact of crude oil price on the current Chinese stock market index (SSE) is negative and insignificant but increases in money supply have a contemporaneous positive but insignificant impact on the current SSE. On the other hand, contemporaneous effect of industrial production is negative but this effect lagged one month is positive. The contemporaneous impact of inflation and its effect lagged one month is positive but only the contemporaneous effect is significant.

The reason why there is a positive long run relationship between crude oil price and Chinese stock index may be that increase in oil price changes may increase the speculation in mining and petrochemicals index, leading to an enhancement in their stock. This is consistent with the study done by Cong and et al. (2008). Another reason for this 
positive relation is due to people's expectations on future economic growth that lead to increasing demand for shares in the market. This finding is supported by the study done by Gogineni (2008). Moreover, the positive long run relationship between crude oil price and stock market index in China may be due to the fact that companies in energy, industrial, material sectors depend on the world business cycle, and they react to increase in crude oil price. Although cost pressure rises due to higher oil price, their profit margins may even be enhanced due to global economic boom. This is consistent with the study done by Weidenmier, Davis and Aliaga-Diaz (2008). The positive long run relationship between money supply and stock market in China could be due to the effect of the injection of public funds into the market which leads to boost corporate earnings. This is consistent with the study done by Mukherjee and Naka (1995). Moreover, this positive long-term relationship between money supply and the stock market could be due to strong pro-cyclical monetary policies implemented in China. This is consistent with Du's (2006) findings.

On the other hand, the negative impact of industrial production on the stock market index in China is due to an increase in the productivity of real capital which raises expected future output. As a result, higher expected market returns cause investors to borrow against expected future output. Increased demand for funds can lead to an increase in interest rate causing a decrease in the present value of future cash flow. Therefore, lower earnings will be achieved, which in turn reduces share prices. Inflation could indicate less unemployment and higher output and income leading to higher stock prices. The positive relationship between inflation and stock market returns in China supports Nelson's (1976) claimed that correlation between current nominal returns and one-period lagged inflation should be direct due to the positive relationship between past and expected inflation rates. Based on equilibrium models, correlation between price volatility and equity returns depend on the source of change in inflation (monetary or real).

\subsection{Cointegraion and VECM result in India}

$$
\mathrm{BSE}=87.72-3.54 \mathrm{COP}-22.53 \mathrm{M} 2+52.51 \mathrm{IP}+0.32 \mathrm{IR}
$$

Based on cointegration equation above, the long-term impact of crude oil price and money supply on the stock market index in Indian is negative. However, the effect of industrial production and inflation rate on the stock index is positive.

\section{Insert Table 6 here}

The contemporaneous effect of crude oil price and industrial production on the current Indian stock market (BSE) is positive and insignificant. On the other hand, the contemporaneous effect of money supply is negative and insignificant. Moreover, the contemporaneous impact of inflation as well as its lagged impact of up to three months is negative. However, only the contemporaneous and three-month lagged impacts are significant.

The negative long run relationship between BSS and oil price is expected as India is one the biggest importers of oil and it uses crude oil much less efficiently, resulting in the oil price risk having a great negative effect on its stock markets. The negative long run impact of money supply in India may be due to its weakly pro-cyclical, neutral or counter-cyclical monetary policy. Moreover, this negative long run effect conforms to the expectation that when money supply increases, it leads to higher inflation and lower returns which is consistent with the study of Abugri (2008).

On the other hand, the positive long-term relationship between industrial production and stock market index in India is a result of an increase in real activities, which lead to stock prices due to its effect on dividends. Moreover, growth in output causes rise in expected future cash flow and corporate profitability. As a result, stock prices increases. This result is consistent with the study of Binswanger (2004). This positive relationship results from the fact that when real activities are expected to grow, it will improve cash flows. This, in turn, influences stock prices positively. Positive long-term relationships between inflation and stock market indices in India may be due to the pro-cyclical monetary policy in this country. Another reason could be that investors in India have an inflation expectation, and thereby want more return for their investment in the market to compensate for an increase in expected risk. This is consistent with the study done by Boucher (2006), who indicates that when inflation increases, the price-earnings ratio declines and expected market return rises. This increase in expected return leads to higher share prices.

\section{Conclusion}

The findings show that in both long and short run, there is a linkage between the four selected macroeconomics variables and stock market indices in China and India. In the long run, the impact of increases in crude oil price in China is positive but in India this effect is negative. In terms of money supply, the impact on Indian stock market is negative, but for China, there is positive impact. The effect of industrial production is negative only in China. In addition the effect of increases in inflation on these stock indices is positive in both countries. In the short run, the 
contemporaneous effect of crude oil price is positive in India. This effect is negative and insignificant in China. The contemporaneous impact of money supply on current Chinese stock market indices is positive but for India, it is negative. However, all these impacts are insignificant. On the other hand, the contemporaneous effect of inflation on current Chinese stock index (SSE) is positive and significant but this effect lagged one month though positive is insignificant. In comparison, in India the contemporaneous effect is negative but insignificant. However, the lagged effects are negative and significant. With increased awareness and knowledge of these kinds of relationships, global investors are able to enhance short and long-term investment decisions-makings since they have the necessary information on the trends and prospects of different economies especially the potential growth of the stock markets.

\section{References}

Abugri, B. A. (2008). Empirical relationship between macroeconomic volatility and stock returns: Evidence from Latin American markets. International Review of Financial Analysis, 17(2), 396-410. http://dx.doi.org/10.1016/j.irfa.2006.09.002

Apergis, N., \& Eleftheriou, S. (2002). Interest rates, inflation, and stock prices: the case of the Athens Stock Exchange. Journal of Policy Modeling, 24(3), 231-236. http://dx.doi.org/10.1016/S0161-8938(02)00105-9

Asprem, M. (1989). Stock prices, asset portfolios and macroeconomic variables in ten European countries. Journal of Banking \& Finance, 13(4-5), 589-612. http://dx.doi.org/10.1016/0378-4266(89)90032-0

Binswanger, M. (2004). How important are fundamentals?--Evidence from a structural VAR model for the stock markets in the US, Japan and Europe. Journal of International Financial Markets, Institutions and Money, 14(2), 185-201. http://dx.doi.org/10.1016/j.intfin.2003.06.001

Boyd, J. H., Levine, R. et al. (2001). The impact of inflation on financial sector performance. Journal of Monetary Economics, 47(2), 221-248. http://dx.doi.org/10.1016/S0304-3932(01)00049-6

Bulmash, S. B., \& Trivoli, G. W. (1991). Time-lagged interactions between stock prices and selected economic variables. Journal of Portfolio Management (SUMMER 1991).

Boucher, C. (2006). Stock prices-inflation puzzle and the predictability of stock market returns. Economics Letters, 90(2), 205-212. http://dx.doi.org/10.1016/j.econlet.2005.08.001

Campbell, J. Y., Lettau, M., Malkiel, B. G., \& Xu, Y. (2001). Have individual stocks become more volatile? An empirical exploration of idiosyncratic risk. Journal of Finance, 56(1), 1-43. http://dx.doi.org/10.1111/0022-1082.00318

Cong, R.-G., Wei, Y.-M., Jiao, J.-L., \& Fan, Y. (2008). Relationships between oil price shocks and stock market: An empirical analysis from China. Energy Policy, 36(9), 3544-3553. http://dx.doi.org/10.1016/j.enpol.2008.06.006

Dickey, D. A., \& Fuller, W. A. (1979). Distribution of the estimators for autoregressive time series with a unit root. Journal of the American statistical association, 74(366), 427-431. http://dx.doi.org/10.2307/2286348

Dickey, D. A., \& Fuller, W. A. (1981). Likelihood ratio statistics for autoregressive time series with a unit root. Econometrica: Journal of the Econometric Society, 49(4), 1057-1072. http://dx.doi.org/10.2307/1912517

Download entire World Economic Outlook database. Retrieved September 25, 2010, from International Monetary Fund website: http://www.imf.org/external/pubs/ft/weo/2010/01/weodata/download.aspx

Du, D. (2006). Monetary policy, stock returns and inflation. Journal of Economics and Business, 58(1), 36-54. http://dx.doi.org/10.1016/j.jeconbus.2005.06.003

Engle, R. F., \& Granger, C. W. J. (1987). Co-integration and error correction: representation, estimation, and testing. Econometrica: Journal of the Econometric Society, 55(2), 251-276. http://dx.doi.org/10.2307/1913236

Energy Profile of China. (2009). Retrieved September 25, 2010, from Energy Information Administration: Official Energy Statistics from the U.S. Government website: http://www.eia.doe.gov/cabs/china/Profile.html

Energy Profile of India. (2009). Retrieved September 25, 2010, from Energy Information Administration: Official Energy Statistics from the U.S. Government website: http://www.eia.doe.gov/cabs/India/Profile.html

Ewing, B. T., \& Thompson, M. A. (2007). Dynamic cyclical comovements of oil prices with industrial production, consumer prices, unemployment, and stock prices. Energy Policy, 35(11), 5535-5540. http://dx.doi.org/10.1016/j.enpol.2007.05.018

Fama, E. F. (1981). Stock Returns, Real Activity, Inflation, and Money. American Economic Review, 71(4), $545-565$ 
Gallagher, L. A., \& Taylor, M. P. (2002). The stock return-inflation puzzle revisited. Economics Letters, 75(2), 147-156. http://dx.doi.org/10.1016/S0165-1765(01)00613-9

Geske, R., \& Roll, R. (1983). The fiscal and monetary linkage between stock returns and inflation. Journal of Finance, 1-33. http://dx.doi.org/10.2307/2327635

Gogineni, S. (2008). The Stock Market Reaction to Oil Price Changes. SSRN.

Johansen, S. (1988). Statistical analysis of cointegration vectors. Journal of economic dynamics and control, 12(2/3), 231-254. http://dx.doi.org/10.1016/0165-1889(88)90041-3

Johansen, S., \& Juselius, K. (1990). Maximum likelihood estimation and inference on cointegration with applications to the demand for money. Oxford Bulletin of Economics and statistics, 52(2), 169-210. http://dx.doi.org/10.1111/j.1468-0084.1990.mp52002003.x

Kim, K.-h. (2003). Dollar exchange rate and stock price: evidence from multivariate cointegration and error correction model. Review of Financial Economics, 12(3), 301-313. http://dx.doi.org/10.1016/S1058-3300(03)00026-0

Lastrapes, W. D., \& Selgin, G. (1995). The liquidity effect: Identifying short-run interest rate dynamics using long-run restrictions. Journal of Macroeconomics, 17(3), 387-404. http://dx.doi.org/10.1016/0164-0704(95)80060-3

Malkiel, B. G. (1982). Risk and return: A new look, National Bureau of Economic Research Cambridge, Mass., USA.

Maysami, R. C., \& Koh, T. S. (2000). A vector error correction model of the Singapore stock market. International Review of Economics \& Finance, 9(1), 79-96. http://dx.doi.org/10.1016/S1059-0560(99)00042-8

Mookerjee, R., \& Yu, Q. (1997). Macroeconomic variables and stock prices in a small open economy: The case of Singapore. Pacific-Basin Finance Journal, 5(3), 377-388. http://dx.doi.org/10.1016/S0927-538X(96)00029-7

Mukherjee, T. K., \& Naka, A. (1995). Dynamic relations between macroeconomic variables and the Japanese stock market: an application of a vector error correction model. Journal of Financial Research, 18, 223-223.

Nandha, M., \& Faff, R. (2008). Does oil move equity prices? A global view. Energy Economics, 30(3), 986-997. http://dx.doi.org/10.1016/j.eneco.2007.09.003

Nasseh, A., \& Strauss, J. (2000). Stock prices and domestic and international macroeconomic activity: a cointegration approach. The Quarterly Review of Economics and Finance, 40(2), 229-245. http://dx.doi.org/10.1016/S1062-9769(99)00054-X

Nelson, C. R. (1976). Inflation and rates of return on common stocks. Journal of Finance, 31(2), 471-483. http://dx.doi.org/10.2307/2326618

Omran, M., \& Pointon, J. (2001). Does the inflation rate affect the performance of the stock market? The case of Egypt. Emerging Markets Review, 2(3), 263-279. http://dx.doi.org/10.1016/S1566-0141(01)00020-6

Park, J., \& Ratti, R. A. (2008). Oil price shocks and stock markets in the U.S. and 13 European countries. Energy Economics, 30(5), 2587-2608. http://dx.doi.org/10.1016/j.eneco.2008.04.003

Peebles, G., \& Wilson, P. (1996). The Singapore Economy, Cheltenham: Edward Elgar.

Pesaran, M. H., Shin, Y. et al. (2001). Bounds testing approaches to the analysis of level relationships. Journal of applied econometrics, 16(3), 289-326. http://dx.doi.org/10.1002/jae.616

Rogalski, R. J., \& Vinso, J. D. (1977). Stock Returns, Money Supply and the Direction of Causality. The Journal of Finance, 32(4), 1017-1030. http://dx.doi.org/10.2307/2326509

Rozeff, M. S. (1974). The Money Supply and The Stock Market, SSRN.

Sadorsky, P. (2001). Risk factors in stock returns of Canadian oil and gas companies. Energy Economics, 23(1), 17-28. http://dx.doi.org/10.1016/S0140-9883(00)00072-4

Sadorsky, P. (2008). Assessing the impact of oil prices on firms of different sizes: Its tough being in the middle. Energy Policy, 36(10), 3854-3861. http://dx.doi.org/10.1016/j.enpol.2008.07.019

Stock, J. H., Watson, M. W. et al. (1989). Interpreting Evidence on Money-Income Causality. Journal of Econometrics, 161-182. http://dx.doi.org/10.1016/0304-4076(89)90035-3

Stock, J. H., \& Watson, M. W. (1993). A simple estimator of cointegrating vectors in higher order integrated systems. Econometrica: Journal of the Econometric Society, 61(4), 783-820. http://dx.doi.org/10.2307/2951763 
Weidenmier, M., Davis, J. H. et al. (2008). Is Sugar Sweeter at the Pump? The Macroeconomic Impact of Brazil's Alternative Energy Program. NBER Working Paper.

Wongbangpo, P., \& Sharma, S. C. (2002). Stock market and macroeconomic fundamental dynamic interactions: ASEAN-5 countries. Journal of Asian Economics, 13, 27-51. http://dx.doi.org/10.1016/S1049-0078(01)00111-7

World Development Indicators. Retrieved September 25, 2010, from World Bank website: http://data.worldbank.org/data-catalog

Table 1. India and China comparison of key indicators

\begin{tabular}{|c|c|c|c|c|}
\hline \multirow[b]{2}{*}{ Indicators } & \multicolumn{2}{|l|}{2008} & \multicolumn{2}{|l|}{2009} \\
\hline & India & China & India & China \\
\hline Size of Population (million) & 1182.06 & 1328.02 & 1199.062 & 1334.74 \\
\hline Type of Government & \multicolumn{2}{|c|}{ Democracy } & \multicolumn{2}{|c|}{ Communist State } \\
\hline Profit remittances on FDI (current US\$) billions & 10.140 & 48.865 & N/A & $\mathrm{N} / \mathrm{A}$ \\
\hline Foreign direct investment, net inflows (BoP, current US\$) bn & 41.168 & 147.791 & 34.577 & 78.192 \\
\hline Portfolio investment, equity (BoP, current US\$) (million) & -15030 & 8721 & 21111 & 28161 \\
\hline Inflation, average consumer prices $\%$ & 8.349 & 5.9 & 10.882 & -0.685 \\
\hline $\begin{array}{l}\text { Total Oil Production } \\
10^{3} \mathrm{bbl} / \text { day }\end{array}$ & 888.42 & $3,986.93$ & 877.47 & $3,995.62$ \\
\hline $\begin{array}{l}\text { Total Oil Consumption } \\
10^{3} \mathrm{bbl} / \text { day }\end{array}$ & 2,962 & 7,831 & 2980 & 8,200 \\
\hline Exports of goods and services ( $\%$ of GDP) & 23.515 & 34.894 & 25.402 & 26.178 \\
\hline Imports of goods and services ( $\%$ of GDP) & 28.954 & 27.198 & 30.066 & 20.925 \\
\hline $\begin{array}{l}\text { Current account balance } \\
\text { USD, bn }\end{array}$ & -26.621 & 426.107 & -25.885 & 283.756 \\
\hline GDP (nominal) USD, bn & 1206.683 & 4519.944 & 1235.975 & 4908.982 \\
\hline GDP (PPP) USD, bn & 3297.836 & 7966.538 & 3526.124 & 8765.24 \\
\hline Money and quasi money (M2) as \% of GDP & 70.026 & 139.885 & 74.631 & 159.378 \\
\hline Quasi money (current LCU) bn & 31634.4 & 30894.9 & 37351.3 & 38.877 .9 \\
\hline Total reserves (includes gold, current US\$) bn & 257 & 1966 & 284 & 2453 \\
\hline
\end{tabular}

Source: Energy Information Administration, International Monetary Fund and World Bank 
Table 2. The summary of selected studies for the determinants of Stock Market Index

\begin{tabular}{|c|c|c|c|c|c|c|c|c|c|c|c|c|c|c|c|c|c|c|c|c|c|c|c|c|c|c|c|c|c|c|}
\hline \multirow[b]{2}{*}{ No. } & & \multicolumn{29}{|c|}{ The relationship between Stock Market Index and its determinants } \\
\hline & Authors & 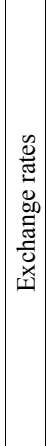 & 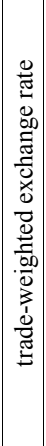 & 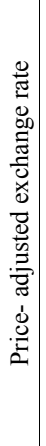 & 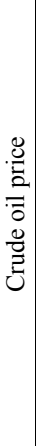 & 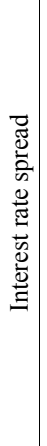 & 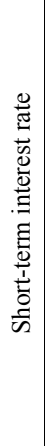 & 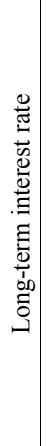 & 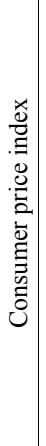 & 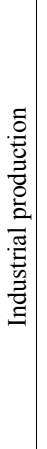 & 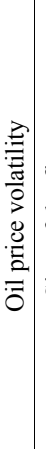 & 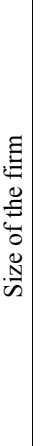 & 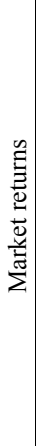 & 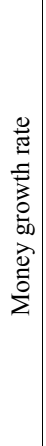 & 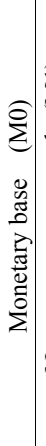 & 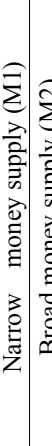 & 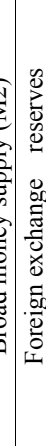 & 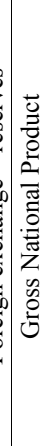 & 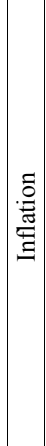 & 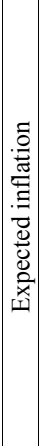 & 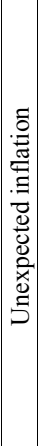 & 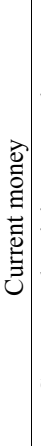 & 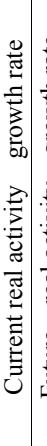 & 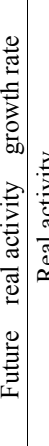 & 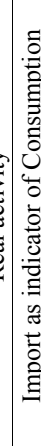 & 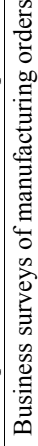 & 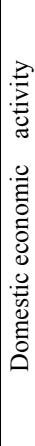 & 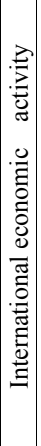 & 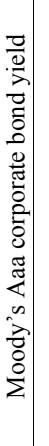 & 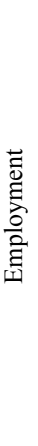 \\
\hline 1. & Sadorsky (2001) & $(\times)$ & & & $(\times)$ & & $(\times)$ & & & & & & & & & & & & & & & & & & & & & & & \\
\hline 2. & Park and Ratti (2008) & & & & & & & & & & $(\times)$ & & & & & & & & & & & & & & & & & & & \\
\hline 3. & Cong et al. (2008) & & & & & & & & & & $(+)$ & & & & & & & & & & & & & & & & & & & \\
\hline 4. & Nandha and Faff (2008) & & & & & & & & & & $(+)$ & & & & & & & & & & & & & & & & & & & \\
\hline 5. & Sadorsky (2008) & & & & $(\times)$ & & & & & & $(\times)($ & $(\times)$ & $(\times)$ & & & & & & & & & & & & & & & & & \\
\hline 6. & Rozeff (1974) & & & & & & & & & & & & & ( ) & & & & & & & & & & & & & & & & \\
\hline 7. & Rogalski and Vinso, (1977) & & & & & & & & & & & & & $(\times)$ & & & & & & & & & & & & & & & & \\
\hline 8. & Mookerjee and Yu (1997) & $(+)$ & & & & & & & & & & & & & & $(x)(x$ & $(\times)$ & & & & & & & & & & & & & \\
\hline 9. & Maysami and Koh (2000) & $(\times)$ & & & & & $(\times)$ & $(\times)$ & & & & & & & & $(x$ & ) & & $(\times)$ & & & & & & & & & & & \\
\hline 10. & Wongbangpo and Sharma (2002) & $(\times)$ & & & & & $(\times)$ & & $(\times)$ & & & & & & & $(x)$ & & $(\times)$ & & & & & & & & & & & & \\
\hline 11. & Fama (1981) & & & & & & & & & & & & & & & & & & & $x)$ & & & & & & & & & & \\
\hline 12. & Geske and Roll (1983) & & & & & & $(\times)$ & & & & & & & & & & & & & & $(x)$ & & & & & & & & & \\
\hline 13. & Asprem (1989) & $(\times)$ & & & & & & $(\times)$ & & & & & & & $(\times)$ & & & & $(x)$ & & & & & & $(x)$ & & & & & $(\times)$ \\
\hline 14. & Nasseh and Strauss (2000) & & & & & & & & & & & & & & & & & & & & & & & & & & & $(\times)$ & & \\
\hline 15. & Omran and Pointon (2001) & & & & & & & & & & & & & & & & & & $(\times)$ & & & & & & & & & & & \\
\hline 16. & Kim (2003) & & $(x)$ & $(\times)$ & & & & & & $(\times)$ & & & & & & & & & $(\times)$ & & & & & & & & & & $(\times)$ & \\
\hline 17. & Apergis and Eleftheriou (2002) & & & & & & $($ ) & & & & & & & & & & & & $(\times)$ & & & & & & & & & & & \\
\hline 18. & $\mathrm{Du}(2006)$ & & & & & & & & $(\times)$ & & & & & & & & & & & & & & & & & & & & & \\
\hline
\end{tabular}

Note: The symbol in the parenthesis denote the relationship between Stock Market Index and its determinants, $(\times)$ and $(+)$ indicate significant and partial significant impact respectively while parenthesis ( ) without symbol indicates that the variable is insignificance at the conventional significant level (i.e. 1, 5, and 10 per cent).

Table 3. The ADF Unit Root Tests Results

\begin{tabular}{lccccc}
\hline & & \multicolumn{2}{c}{ Level } & \multicolumn{2}{c}{$1^{\text {st }}$ Difference } \\
\hline Countries & Index & C & C\&T & C & C\& T \\
\hline \multirow{4}{*}{ China } & SSE & -1.88 & -1.89 & $-5.58^{* *}$ & $-5.57^{* *}$ \\
& COP & -2.36 & -1.99 & $-9.7^{* *}$ & $-9.89^{* *}$ \\
& M2 & 1.44 & $-3.68^{*}$ & $-10.26^{* *}$ & $-6.91^{* *}$ \\
& IP & -2.25 & -1.72 & $-13.66^{* *}$ & $-10.37^{* *}$ \\
& IR & -1.63 & -2.01 & $-8.99^{* *}$ & $-9.02^{* *}$ \\
\hline \multirow{4}{*}{ India } & BSE & -1.14 & -1.22 & $-9.62^{* *}$ & $-9.61^{* *}$ \\
& COP & -2.36 & -1.99 & $-9.70^{* *}$ & $-9.89^{* *}$ \\
& M2 & 0.056 & -2.86 & $-11.53^{* *}$ & $-8.42^{* *}$ \\
& IP & -0.30 & $-3.81^{*}$ & $-20.88^{* *}$ & $-20.82^{* *}$ \\
\hline
\end{tabular}

Notes: Asterisk $*$ and $* *$ denote significance at $5 \%$ and $1 \%$ value, respectively.

C stands for "Intercept" and C\&T represents "Trend and Intercept". 
Table 4. Cointegration test results for stock market and its variables

\begin{tabular}{|c|c|c|c|c|c|}
\hline Countries & $\mathbf{H}_{0}$ & Trace Test & $\begin{array}{l}5 \% \text { Critical } \\
\text { Value }\end{array}$ & $\begin{array}{c}\text { Maximum } \\
\text { Eigenvalues Tests }\end{array}$ & $\begin{array}{l}5 \% \text { Critical } \\
\text { Value }\end{array}$ \\
\hline \multirow{5}{*}{ China } & $\mathbf{r}=\mathbf{0}$ & $108.03 * *$ & 76.97 & $47.64 * *$ & 34.80 \\
\hline & $r \leq 1$ & $60.67 *$ & 54.07 & $30.36^{*}$ & 28.58 \\
\hline & $r \leq 2$ & 30.31 & 35.19 & 18.15 & 22.29 \\
\hline & $r \leq 3$ & 12.16 & 20.26 & 10.29 & 15.89 \\
\hline & $r \leq 4$ & 1.86 & 9.16 & 1.86 & 9.16 \\
\hline \multirow{5}{*}{ India } & $\mathbf{r}=\mathbf{0}$ & $118.54 * *$ & 76.97 & $59.17 * *$ & 34.80 \\
\hline & $r \leq 1$ & $59.37 *$ & 54.07 & $27.51 *$ & 28.58 \\
\hline & $r \leq 2$ & 31.86 & 35.19 & 14.43 & 22.29 \\
\hline & $r \leq 3$ & 17.43 & 20.26 & 11.12 & 15.89 \\
\hline & $r \leq 4$ & 6.31 & 9.16 & 6.31 & 9.16 \\
\hline
\end{tabular}

Note: Asterisk * and $* *$ denote significance at $5 \%$ and $1 \%$ value, respectively

Table 5. Vector Error-correction model for SSE

\begin{tabular}{ccccccccccc}
\hline$\Delta \mathrm{SSE}$ & $\Delta \mathrm{SSE}_{\mathrm{t}-1}$ & $\Delta \mathrm{SSE}_{\mathrm{t}-2}$ & $\Delta \mathrm{COP}_{\mathrm{t}}$ & $\Delta \mathrm{M} 2_{\mathrm{t}}$ & $\Delta \mathrm{IP}_{\mathrm{t}}$ & $\Delta \mathrm{IP}_{\mathrm{t}-1}$ & $\Delta \mathrm{IR}_{\mathrm{t}}$ & $\Delta \mathrm{IR}_{\mathrm{t}-1}$ & $\mathrm{ECT}_{\mathrm{t}-1}$ \\
\hline$\beta$ & +0.124 & $+0.25^{* * *}$ & -0.021 & +0.336 & -0.229 & +0.582 & $0.035^{* *}$ & +0.027 & $-0046^{*}$ \\
& $(1.28)$ & $(2.55)$ & $(0.29)$ & $(-0.44)$ & $(-0.78)$ & $(-1.7)$ & $(2.2)$ & $(1.83)$ & $(-2.07)$ \\
\hline
\end{tabular}

Note: $t$ statistics are included in parentheses. Asterisk *,**and *** denote significance at the $10 \%, 5 \%$ and $1 \%$ value.

Table 6. Vector Error-correction model for BSE

\begin{tabular}{cccccccccc}
\hline$\Delta \mathrm{BSE}$ & $\Delta \mathrm{BSE}_{\mathrm{t}-1}$ & $\Delta \mathrm{COP}_{\mathrm{t}}$ & $\Delta \mathrm{M} 2_{\mathrm{t}}$ & $\Delta \mathrm{IP}_{\mathrm{t}}$ & $\Delta \mathrm{IR}_{\mathrm{t}}$ & $\Delta \mathrm{IR}_{\mathrm{t}-1}$ & $\Delta \mathrm{IR}_{\mathrm{t}-2}$ & $\Delta \mathrm{IR}_{\mathrm{t}-3}$ & $\mathrm{ECT}_{\mathrm{t}-1}$ \\
$\beta$ & 0.0701 & 0.064 & -0.03 & +0.087 & $-0.022^{*}$ & -0.009 & -0.006 & $-0.02 *$ & -0.00559 \\
& $(0.709)$ & $(0.796)$ & $(-0.071)$ & $(0.428)$ & $(-1.846)$ & $(-0.735)$ & $(-0.458)$ & $(-1.72)$ & $(-0.125)$ \\
\hline
\end{tabular}

Note: $t$ statistics are included in parentheses. Asterisk *, **and *** denote significance at the $10 \%, 5 \%$ and $1 \%$ value. 